\title{
SISTIM PENGENDALIAN KREDIT UNTUK MEMPERTAHANKAN LIKUIDITAS PADA PT. BANK NAGARI CABANG PAINAN.
}

\author{
Sarah Arnila, Jhon Fernos \\ Akademi Keuangan Perbankan "Pembangunan" Padang \\ Jhonfernos@akbpstie.ac.id
}

\begin{abstract}
For CR ratio PT. Nagari Bank Painan Branch 2014-2016 can be said to be healthy, because it is above the BI standard, namely:

$>=4.05 \%$ : healthy. $>=3.30 \%-<4.05 \%$ : quite healthy $>2.55 \%-<3.30 \%$ :

unhealthy 2.55\%: unhealthy For QR ratio, PT. Bank Nagari Painan branch in 2014-2016 can be said to be liquid if QR is above 100\% or 1: 1, and if it is below $80 \%$ or 0.8: 1 then this will have a bad impact on the bank, because it can cause financial problems bank.For the LDR ratio of PT. Bank Nagari Painan branch which was obtained in 2014-2016 can be said to be healthy, if it is below the standard set by BI, namely: <= 94.75\%: healthy $94.75 \%$ 98.50\%: healthy enough> 98.50\% - <= 102.25\%: Unhealthy> 102.25\% unhealthy
\end{abstract}

Keywords: Credit, Bank, Liquidity

\section{PENDAHULUAN}

Pertumbuhan perekonomian di indonesia sangatlah tergantung pada adanya pertumbuhan diberbagai sektor yang secara langsung atau tidak langsung akan mempengaruhinya.

Berdasarkan pada undang-undang republik indonesia No 7 tahun 1992 tentang perbankan yang telah diubah dengan undang-undang No 10 tahun 1998, perbankan adalah segala sesuatu yang menyangkut bank mencakup kelembagaan, kegiatan usaha serta cara dan proses dalam melaksanakan kegiatan usahanya.

Dalam perkembangan perekonomian Indonesia pada umumnya banyak ditemui permasalahan-permasalahan pada usaha perbankan diantaranya adalah:

1. Kurangnya permodalan dalam penyelenggaraan usaha.

2. Kurang bagusnya pengendalian kredit yang dijalankan oleh pihak bank sehingga mempunyai tingkat pertumbuhan bank dan perkembangan usahanya.

3. Kurang baiknya pengendalian kredit oleh pihak bank sehingga menimbulkan masalahmasalah bagi bank dalam kegiatan perkreditan. 
Dari pemaparan latar belakang diatas, penulis tertarik untuk melakukan suatu analisa berkaitan dengan pengendalian kredit dan likuiditas bank, adapun objek penelitian dari penulis adalah Bank Nagari Cabang Painan. Maka untuk itu penulis akan melakukan penelitian dalam tugas akhir ini dengan judul : "Sistim Pengendalian Kredit Untuk Mempertahankan Likuiditas Pada PT. Bank Nagari Cabang painan ”.

Adapun perumusan masalah dalam penulisan tugas akhir ini yaitu: bagaimana Sistim pengendalian kredit untuk mempertahankan likuiditas pada PT. Bank Nagari Cabang Painan.

\section{LANDASAN TEORI Pengertian Bank}

Bank merupakan salah satu lembaga keuangan yang umumnya didirikan dengan kewenangan untuk menerima simpanan uang, meminjamkan uang, dan menerbitkan promes atau yang dikenal sebagai banknote.

Sedangkan Pengertian bank menurut Suyatno (1993:10) adalah usaha yang bertujuan untuk memuaskan kebutuhan kredit, baik dengan alat-alat pembayaran sendiri atau dengan uang yang diperoleh dari orang lain maupun dengan jalan memperedarkan alatalat penukaran baru berupa uang giral.

Menurut undang-undang Republik Indonesia Nomor 10 Tahun 1998 tentang perubahan undang-undang Nomor 7 tahun 1992 tentang perbankan, bank terdiri atas dua jenis yaitu :

a. Bank Umum

Bank umum adalah bank yang melaksanakan kegiatan usaha secara konvensional dan atau berdasarkan prinsip syariah yang dalam kegiatannya memberikan jasa lalu lintas pembayaran.

b. Bank Perkreditan Rakyat (BPR)

BPR adalah bank yang melaksanakan kegiatan usaha secara konvensional atau berdasarkan prinsip syariah yang dalam kegiatan tidak memberikan jasa lalu lintas pembayaran.

Bank mempunyai fungsi yaitu :

1. Penghimpun dana maka bank memiliki beberapa sumber yang secara garis besar ada tiga sumber yaitu :

a. Dana yang bersumber dari bank sendiri yang berupa setoran modal waktu pendirian.

b. Dana yang berasal dari masyarakat luas yang dikumpulkan melalui usaha perbankan.

c. Dana yang bersumber dari lembaga keuangan yang diperoleh dari pinjaman dana yang berupa kredit Likuiditas dan Call Money( dana yang sewaktu-waktu dapat ditarik oleh bank-bank yang meminjam).

2. Penyalur dana-dana yang terkumpul oleh bank disalurkan kepada masyarakat dalam bentuk pemberian kredit, pembelian surat-surat berharga, penyertaan, dan pemilikan harta tetap.

3. Pelayanan jasa bank dalam mengembangkan tugas sebagai pelayanan lalu lintas pembayaran uang. 


\section{Pengertian Likuiditas}

Likuiditas adalah kemampuan perusahaan untuk memenuhi kewajiban-kewajiban hutang-hutang nya, dapat membayar kembali semua deposannya serta dapat memenuhi permintaan kredit yang diajukan para debitur tanpa terjadi penangguhan. Menurut pengertian ini bank dikatakan likuid apabila :

1. Bank tersebut memiliki cash assets sebesar kebutuhan yang akan digunakan untuk memenuhi likuiditasnya.

2. Bank tersebut memiliki cash assets yang lebih kecil dari yang tersebut diatas, tetapi yang bersangkutan juga memiliki asset lainnya (khususnya surat-surat berharga) yang dapat dicairkan sewaktu-waktu tanpa mngalami penurunan nilai pasarnya.

3. Bank tersebut mempunyai kemampun untuk menciptakan cash assets baru melalui berbagai bentuk hutang.

\section{Jenis dan Sumber Alat Likuiditas}

Menurut terminologi yang berlaku umum dalam dunia perbankan, dapat disebutkan bahwa jenis-jenis alat likuiditas yang dimiliki oleh bank adalah :

1. Kas atau uang tunai (kertas dan logam) yang tersimpan dalam brankas (khasana) bank tersebut.

2. Saldo dana milik bank tersebut yang terdapat pada Bank Sentral (Saldo Giro BI).

3. Tagihan atau deposito pada bank lain, termasuk bank koresponden.

4. Cek yang diterima, tetapi masih dalam proses penguangan pada bank Sentral dan bank koresponden.

Adapun menurut sumbernya, suatu bank dapat memperoleh alat-alat likuiditas yang diperlukan tersebut diatas dari berbagai sumber, yaitu :

1. Asset bank yang segera jatuh tempo

Kredit pinjaman kepada debitur atau cicilan pinjaman yang akan jatuh tempo dapat dianggap sebagai sumber likuiditas. Sedangkan kewajiban-kewajiban kepada pihak ketiga yang harus ditutup dengan alat likuiditas tersebut dimasukkan pada pos-pos aktiva. Klasifikasi masing-masing pos tersebut dapat diuraikan sebagai berikut :

a. Aktiva

1) Kas, yang dimasukkan kedalam pos ini adalah uang kartal yang ada dalam kas berupa uang kertas, uang logam. dikeluarkan oleh Bank Sentral (Bank Indonesia)

2) Bank Indonesia, yaitu semua simpanan atau tagihan bank bersangkutan dalam Rupiah kepada Bank Indonesia, seperti saldo giro BI dan lainnya.

3) Surat-Surat berharga dan tagihan lainnya, Yang termasuk golongan ini adalah surat-surat berharga dalam rupiah yang dibeli atau dimiliki oleh bank bersangkutan.

b. Pasiva

1) Giro, yaitu simpanan-simpanan dalam rupiah oleh pihak ketiga bukan bank, yang penarikannnya dapat dilakukan setiap saat dengan menggunakan cek, surat perintah pembayaran lainnya atau dengan cara pemindahbukuan.

2) Simpanan Berjangka, yaitu simpanan dalam bentuk deposito berjangka,deposito asuaransi dan deposito on call dalam rupiah pihak ketiga bukan bank, yang penarikannya dapat dilakukan menurut jangka waktu yang disepakati. 
3) Tabungan, yaitu simpanan dalam rupiah ketiga bukan bank, yang penarikannya hanya dapat dilakukan menurut syarat dan cara tertentu.

4) Kewajiban lainnya yang segera jatuh tempo, yaitu semua kewajiban dalam rupiah yang setiap saat dapat ditagih oleh pemiliknya dan harus dibayar, misalnya kiriman uang.

\section{Prinsip-prinsip Pengelolaan Likuiditas}

Pengelolaan likuiditas harus dilakukan dengan cara hati-hati dengan memperhatikan prinsip-prinsip yang ada. Oleh karena itu dalam pengelolaan likuiditas bank perlu diperhatikan beberapa prinsip pengelolaan likuiditas yaitu:

1. Bank harus memiliki sumber dana inti (core source of fund) sesuai dengan sifat bank yang bersangkutan maupun pasar uang dan sumber dana yang ada dimasyarakat.

2. Bank harus mengelola sumber-sumber dana maupun penenmpatannya dengan hati-hati.

3. Bank harus diperhatikan different price for dfferent custumer didalam penempatan dananya.

4. Bank harus waspada bahwa tingkat suku bunga dana tersebut selalu berfluktuasi, naik turun dengan gerak yang susah ditebak sebelumnya (volatile).

5. Bank harus secara terkoordinasikan apabila akan menanamkan sumber-sumber dananya ke aktiva

\section{Tujuan dan Manfaat Pengeloaan Likuiditas}

Pengelolaan likuiditas merupakan faktor yang sangat penting dalam operasional perbankan, bahkan sangat menentukan bagi kemampuan suatu bank untuk bertahan dan berkembang dalam persaingan usaha yang makin kompetitif. Tujuan dan manfaat dari pengelolaan likuiditas suatu bank secara garis besar adalah :

1. Untuk mengukur kemampuan perusahaan membayar kewajiban atau utang yang segera jatuh tempo pada saat ditagih.

2. Untuk melihat kondisi dan posisi likuiditas perusahaan dari waktu ke waktu dengan membandingkannya untuk beberapa periode.

3. Sebagai alat perencanaan kedepan, terutama yang berkaitan dengan perencanaan kas dan hutang.

4. Untuk mengukur beberapa besar uang kas yang tesedia untuk membayar hutang.

5. Untuk melihat kelemahan yang dimiliki perusahaan, dari masing-masing komponen yang ada diaktiva lancar dan utang lancar.

6. Untuk mengukur kemampuan perusahaan membayar kewajiban jangka pendek dengan aktiva lancar secara keseluruhan.

7. Untuk mengukur kemampuan perusahaan membayar kewajiban jangka pendek dengan aktiva lancar tanpa memperhitungkan persediaan dan utang yang dianggap likuiditasnya lebih rendah.

8. Menjadi alat pemicu bagi pihak manajemen untuk memperbaiki kinerjanya.

\section{Metode dan pendekatan Dalam Pengelolaan Likuiditas Bank}

Secara umum metode yang digunakan oleh manajemen perbankan dalam menetapkan policy likuiditasnya berbeda antara suatu bank dengan bank yang lainnya yaitu

1. Self liquiditing apporoach, yaitu pendekatan peningkatan likuiditas bank melalui peningkatan pembayaran kembali kredit dan penanaman dalam surat berharga, sesuai dengan tanggal jatuh temponya. 
2. New fund, yaitu meningkatkan likuiditas dengan cara menciptakan sumber-sumber dana yang baru..

3. Borrower Warning Flow, yaitu meningkatkan likuiditas melalui usaha yang lebih giat dalam menjaga kelancaran penerimaan angsuran dan bunga dari kredit yang diberikannya.

4. Reserve Discount Window to Central Bank As lender of Last Resort, yaitu meningkatkan likuiditas dengan jalan mengadakan pinjaman ke Bank Sentral sebagai pemberi pinjaman yang terakhir.

\section{METODE PENELITIAN} cara yaitu:

Didalam penelitian ini penulis menggunakan metode pengumpulan data dengan dua

1. Metode Pengumpulan Data

a. Study Lapangan (Field Research)

Peninjauan langsung ke objek penelitian yang dipilih untuk meneliti hasil data primer. Penelitian ini akan dapat membantu penulisan untuk melengkapi data yang diperlukan.

b. Study Perpustakaan (Library Research)

Penelitian ini dilakukan ke perpustakaan berupa buku-buku ilmiah dan tulisantulisan yang berhubungan dengan pembahasan yang dilakukan.

2. Metode Analisis Data

Dalam menganalisa data, menggunakan analisa data kualitatif dan kuantitatif. Dimana metode kualitatif menggambarkan, memahami dan menjelaskan data yang diteliti selama penelitian berlangsung, sedangkan metode kuantitatif menganalisa perhitungan likuiditas pada PT. Bank Nagari Cabang Painan

\section{HASIL DAN PEMBAHASAN}

\section{Analisa Sistim Pengendalian kredit Untuk Mempertahankan Likuiditas}

Kredit adalah hak untuk menerima pemabayaran atau berkewajiban untuk melakukan pembayaran pada waktu diminta, atau pada waktu yang akan datang karena penyerahan barang-barang sekarang.

Syarat pemberian kredit

a. Character yaitu penilaian character pada dasarnya dimaksudkan untuk mengetahui kemampuan peminjam untuk memenuhi kewajibannya

b. Capacity yaitu adalah kemampuan pemohon dalam menjalankan usahanya guna memperoleh laba yang diharapkan.

c. Capital yaitu adalah dana yang dimiliki pemohon untuk menjalankan dan memelihara kelangsungan usahanya.

d. Collateral yaitu adalah jaminan yang diserahkan pemohon atas kredit yang akan diterimanya.

e. Condition Economy yaitu adalah keadaanekonomi pada suatu saat yang dapat mempengaruhi maju mundurnya perusahan.

\section{Tujuan dan fungsi kredit}

Tujuan kredit mencakup permasalahan yang luas salah satunya ada dua tujuan pokok yang saling berkaitan dari kredit adalah :

1. Profitabilit yaitu suatu tujuan untuk memperoleh hasil dari kredit berupa keuntungan yang diperoleh dari penggunaan pemungutan bunga. 
2. Safet yaitu keamanan dari prestasi ataupun fasilitas yang diberikan harus benarbenar terjamin sehingga tujuan dari profitability dapat benar-benar tercapai tanpa hambatan yang berarti.

Fungsi kredit suatu bank dapat dilihat dari kegiatan-kegiatan ekonomi sebagai berikut :

1. Kredit dapat meningkatkan utility dan daya guna dari uang atau modal

2. Kredit dapat meningkatkan utility atau daya guna barang

3. Kredit dapat meningkatkan peredaran dan lalu lintas uang.

4. Kredit dapat meningkatkan kegiatan masyarakat.

5. Kredit sebagai alat stabilisator ekonomi.

6. Kredit sebagai jembatan peningkatan pendapatan nasional.

7. Kredit sebagai alat untuk meningkatkan hubungan internasional.

Unsur-unsur kredit

1. Kepercayan yaitu seseorang baru dapat memberikan jasa atau prestasi kepada pihak lain,dimana jasa tersebut akan dibayar suatu waktu tertentu atau dikemudian hari maka yang member jasa tersebut kepada pihak lain ialah adanya kepercayan, bahwa jasa tersebut tepat dibayar pada waktunya.

2. Resiko yaitu karena antara prestasi yang diberikan dan diterimanya kembali prestasi tersebut terdapat unsur waktu, maka timbullah suatu resiko yang ditanggung oleh pihak pemberi jasa.

\section{Pembahasan}

Secara akuntansi keuangan atau perbankan perhitungan atau pengukuran likuiditas dapat dilakukan dengan perhitungan ratio yang menggambarkan hubungan timbal balik antara asset dan liabilities.

Adapun rumus-rumus perhitungan ratio likuiditas yangsering digunakan adalah sebagai berikut :

a. Cash Ratio (CR)

Cash Ratio menunjukan kemampuan perusahaan yang melunasi kewajibankewajibannya yang segera harus dibayar dengan alat-alat likuiditas yang dimlikinya. Semakin tinggi rasio ini berarti menunjukan semakin tinggi kemampuan likuiditasnya. Berdasarkan ketentuan Bank Indonesia atau BI cash ratio dapat dikatakan sehat atau lancar jika lebih besar dari 4,05\%. Berdasarkan data yang diperoleh cash ratio Bank Nagari Cabang Painan selama tahun 2014 sampai dengan tahun 2016 ditunjukan pada tabel dibawah ini. 
Tabel 1

Perhitungan Cash Ratio PT. Bank Nagari Cabang Painan

Tahun 2014-2016

(Dalam Ribuan Rupiah)

\begin{tabular}{|c|c|c|c|c|}
\hline & \multirow{2}{*}{ Komponen } & \multicolumn{3}{|c|}{ Tahun } \\
\hline & & 2014 & 2015 & 2016 \\
\hline $\begin{array}{r}\text { 1. Cash } \\
\text { a. }\end{array}$ & $\begin{array}{l}\text { Ratio } \\
\text { Alat Likuid } \\
\text { - Kas } \\
\text { - Antar Bank } \\
\text { Aktiva } \\
\text { Jumlah } \\
\text { Hutang Lancar } \\
\text { - Kewajiban } \\
\text { - Segera } \\
\text { - Tabungan } \\
\text { Deposito } \\
\text { Jumlah }\end{array}$ & $\begin{array}{c}16.127 .947 \\
194.583 \\
16.322 .530 \\
4.681 .488 \\
104.388 \\
60.442 .250 \\
65.228 .126\end{array}$ & $\begin{array}{l}3.337 .551 \\
194.614 \\
3.532 .165 \\
5.454 .741 \\
133.208 \\
74.955 .650 \\
80.543 .599\end{array}$ & $\begin{array}{r}24.552 .943 \\
4.319 . \\
24.557 .262 \\
12.233 .987 \\
113.180 \\
37.396 .750 \\
49.743 .917\end{array}$ \\
\hline
\end{tabular}

Sumber : Data Olahan

Dengan formula :

$$
C R=\frac{A L}{H L} \times 100 \%
$$

Alat Likuiq $=$ Kas + Antar Bank Aktiva

Hutang Lancar $=$ Kewajiban yang segera harus dibayar + DPK

1. Tahun 2014

$$
\begin{aligned}
C R & =\frac{R p 16.127 .947+R p 194.583}{R p 16.951 .226} \\
& =\mathrm{Rp} 96,29 \%
\end{aligned}
$$

Artinya, bank mampu dalam memenuhi kewajibannya dengan menggunakan alat likuid yang dimiliki oleh bank dengan CR sebesar 96,29\%. Hal ini menunjukan bahwa tahun 2014 cash ratio bank dapat dikatakan sehat karena $>=4,05 \%$.

2. Tahun 2015

$$
\begin{aligned}
C R & =\frac{R p 33.337 .551+R p 194.614}{R p 21.436 .604} \times 100 \% \\
& =R p 15,64 \%
\end{aligned}
$$

Artinya, bank mampu dalam memenuhi kewajibannya dengan menggunakan alat likuid yang dimiliki oleh bank dengan CR sebesar 15,64\%. Hal ini 
menunjukan bahwa tahun 2015 cash ratio bank dapat dikatakn seht karena $>=4,05 \%$.

3. Tahun 2016

$$
\begin{aligned}
C R & =\frac{R p 24.552 .943+4.319}{R p 16.281 .143} \times 100 \% \\
& =\quad \operatorname{Rp} 15,08 \%
\end{aligned}
$$

Artinya, bank mampu dalam memenuhi kewajibannya dengan menggunakan alat likuid yang dimilki oleh bank dengan CR sebesar 15,08\%. Hal ini menunjukan bahwa tahun 2016 cash ratio bank dapat dikatakan sehat karena $>=4,05 \%$.

Dari analisa CR diatas secara keseluruhan dapat ditarik kesimpulan,bahwa CR yang dimiliki PT. Bank Nagari Cabang Painan setiap periodenya mampu dalam memenuhi kewajibannya, hal ini baik bagi bank. Namun darai sisi pengelolaan dananya, masih terlihat banyak dana yang menganggur atau idle money. Jika cash ratio ini terus besar dalam setiap periode dari yang telah ditetapkan, maka hal initidak baik bagi bank. OLeh karena itu, sebaik nya bank menyalurkan dana tersebut dalam bentuk kredit.

\section{b. Quick Ratio(QR)}

Quick Ratio menggambarkan kemampuan bank untuk membayar kembali simpanan para nasabahnya dengan alat yang paling likuid yang dimiliki oleh bank tersebut. Berdasarkan data yang diperoleh quick ratio Bank Nagari cabang Painanselama tahun 2014 sampai dengan 2016 ditunjukan pada tabel dibawah ini.

Tabel 3

Perhitungan Quick Ratio Bank Nagari Cabang Painan

Tahun 2014-2016

\begin{tabular}{|c|c|c|c|c|}
\hline \multirow{12}{*}{1.} & \multirow[b]{2}{*}{ Ecomponen } & \multicolumn{3}{|c|}{ Tahun } \\
\hline & & 2014 & 2015 & 2016 \\
\hline & exsick Rasio & & & \\
\hline & a. Alat likuid & & & \\
\hline & - KCas & 16.127 .947 & 33.337 .551 & 24.552 .943 \\
\hline & - Antar & 194.583 & 194.614 & 4.319 \\
\hline & Bank Alliva & 16.322 .531 & 33.532 .165 & 24.557 .262 \\
\hline & Jumlah & & & \\
\hline & b. Futang I ancar & $104.38 s$ & 133.208 & 113.180 \\
\hline & - Tabungan & 60.442 .250 & 74.955 .650 & 37.396 .750 \\
\hline & - Deposito & 60.546 .038 & 75.008 .858 & 37.509 .930 \\
\hline & Jumlah & & & \\
\hline
\end{tabular}

(Dalam Ribuan Rupiah)

Sumber : Data Olahan 
Dengan Formula :

$$
Q R=\frac{A L}{D P K} \times 100 \%
$$

Alat likuid $=$ Kas + Antar Bank Aktiva

Dana Pihak Ketiga $=$ Tabungan + Deposito Berjangka

1. Tahun 2014

$$
\begin{aligned}
Q R & =\frac{R p 16.127 .947+194.583}{16.483 .077} \times 100 \% \\
& =R p 99,02 \%
\end{aligned}
$$

Artinya kemampuan Bank Nagari Cabang Painan dalam memenuhi kewajibannya terhadap para deposan dengan harta yang paling tinggi, ini dapat dilihat dari hasil QR 99,02\% dengan analisis bahwa Rp.1,00 deposito dapat dijamin oleh 0,9902 alat likuid yang dimiliki bank.

2. Tahun 2015

$$
\begin{aligned}
Q R & =\frac{R p 33.337 .551+194.614}{20.816 .429} \times 100 \% \\
& =61,08 \%
\end{aligned}
$$

Artinya kemampuan Bank Nagari Cabang Painan dalam memenuhi kewajibannya terhadap para deposan dengan harta yang paling tinggi, ini dapat dilihat dari hasil QR 61,08 \% dengan analisis bahwa Rp.1,00 deposito dapat dijamin oleh 0,6108 alat likuid yang dimiliki bank.

3. Tahun 2016

$$
\begin{aligned}
\mathrm{QR} & =\frac{24.552 .943+4.319}{15.057 .744} \times 100 \% \\
& =63,08 \%
\end{aligned}
$$

Artinya kemampuan Bank Nagari Cabang Painan dalam memenuhi kewajibannyaterhadap para deposan dengan harta yang paling tinggi, ini dapat dilihat dari hasil QR 63,08 \% dengan analisis bahwa Rp.1,00 deposito dapat dijamin oleh 0,6308 alat likuid yang dimilki bank. 
Dari analisis diatas, dapat ditarik kesimpulan bahwa hasil QR dalam setip periode berada diatas standar yang telah ditetapkan yaitu 100\%. Hal ini membuktikan bahwa PT. Bank Nagari Cabang Painan dalam keadaan likuid Jika dillihat dari segi QR, karena bank mampu menutupi kewajibannya dengan menggunakan alat likuid bank.

Namun jika dilihat pada tahun 2014-2016 QR bank terlalu tinggi, sehingga dari segi pengelolaan dananya, bank memiliki asset lancar terlalu banyak sehingga dapat menimbulkan idle moneyatau dana menganggur. Hal ini tentunya tidak baik bagi bank,Untuk itu bank dapat menyediakan asset sesuai dengan kebutuhan dan sisanya bank dapat menyalurkan asset tersebut melalui pemberian kredit kepada nasabah.

c. Loan to Deposit Ratio (LDR)

Loan to Deposit Ratio merupakan perbandingan antar kredit terhadap dana yang diterima bank, Dana yang diterima bank meliputi deposito dan tabungan, pinjaman bukan dari bank lain lebih dari 3 bulan. Deposito dan pinjaman dari bank lain lebih dari 3 bulan, modal ini dan modal pinjaman.

Ratio ini digunakan untuk mengukur kemampuan bank dalam membayar kembali penarikan dan yang dilakukan oleh deposan dengan mengendalkan kredit yang diberikan sebagai sumber likuiitasnya. Semakin tinggi rasio ini, maka menunjukan tingkat kemampuan bank dalam membayar kembali penarikan danayang dilakukan oleh deposan. Menurut standar BI untuk rasio LDR memiliki batasan dibawah94,75\% dikatakan LANCAR. Berdasarkan data yang diperoleh cash ratio Bank Nagari Cabang Painan tahun 2014 sampai dengan tahun 2016 dapat ditunjukan pada tabel dibawah ini.

Tabel 4

Perhitungan Loand To Deposit Ratio Bank Nagari Cabang Painan

Tahun 2014-2016

(Dalam Ribuan Rupiah)

\begin{tabular}{|c|c|c|c}
\hline \multirow{2}{*}{ Komponen } & \multicolumn{3}{|c}{ Tahun } \\
\cline { 2 - 4 } & \multicolumn{1}{|c}{2014} & 2015 & \multicolumn{1}{|c}{2016} \\
\hline 1. Loand To Depos it Ratio & & 9.040 .344 & 9.308 .978 \\
a. Kredit yang & 17.633 .279 & 133.208 & 113.180 \\
diberikan & 104.388 & 74.955 .650 & 37.396 .750 \\
b. Dana Pihak Ketiga dan & 60.442 .250$. & 84.129 .202 & 46.818 .908 \\
Modal & 78.179 .917 & 159.218 .060 & 84.328 .838 \\
- Tabungan & 138.726 .555 & & \\
- Deposito & & & \\
- Modal & & & \\
Jumlah & & & \\
\end{tabular}

Sumber : Data Olahan 


$$
L D R=\frac{\text { TotalLoand }}{\text { TotalDeposit }} \times 100 \%
$$

Total Loand $=$ Kredit Yang Diberikan

Total Deposit : Tabungan + Deposito + Modal

1. Tahun 2014

$$
\mathrm{LDR}=\frac{R p 17.633 .279}{R p 34.729 .482} \times 100 \%=50,77 \%
$$

Artinya, bank mampu dalam membayar kembali penarikan dana yang dilakukan oleh nasabah dengan menggunakan kredit yang diberikan bank dengan dana yang diterima oleh bank adalah sebesar 50,77\%. Hal ini menunjukan bahwa tahun 2014 bank dikatakan lancar atau sehat, karena berada pada batasan $<=94,75 \%$ yang telah ditetapkan BI.

2. Tahun 2015

$$
L D R=\frac{R p 9.040 .344}{R p 42.536 .893} \times 100 \%=21,25 \%
$$

Artinya, bank mampu dalam membayar kembali penarikan dana yang dilakukan oleh nasabah dengan menggunakaan kredit yang diberikan bank dengan dana yang diterima oleh bank adalah sebesar $21,25 \%$. Hal ini menunjukan bahwa tahun 2015 bank dikatakan lancar atau sehat,karena berada pada batasan $<=94,75 \%$ yang telah ditetapkan BI.

3.Tahun 2016

$$
L D R=\frac{R p 9.308 .978}{R p 31.046 .386} \times 100 \%=29,98 \%
$$

Artinya, bank mampu dalam membayar kembali penarikan danma yang dilakukan oleh nasabah dengan menggunakan kredit yang diberikan bankdengan dana yang diterima oleh bank adalah sebesar $29,98 \%$. Hal ini menunjukan bahwa tahun 2016 bank dikatakan lancar atau sehat, karena berada pada batasan $<=94,75 \%$ yang telah ditetapkan BI.

Dari analisis diatas, secara keseluruhan dapat ditarik kesimpulan bahwa PT. Bank Nagari Cabang Painan mampu membayar kembali penarikan dana yang dilakukan oleh nasabah dengan menggunkan kredit yang diberikan yang diberikan bank dengan dana yang diterima oleh bank. Hal ini dibuktikandengan perhitungan LDR, bahwa setiap periodenya bank berda pada batas $<=94,75 \%$ yang artinya tingkat likuiditas bank adalah sehat.

Untuk itu bank perlu menjaga tingkat likuiditasnya, dengan cara menyediakan dana sesuai dengan kebutuhan dan sisanya bank dapat menggunakan dana tersebut melalui penyaluran kredit, agar terhindar dari idle money dimana dana yang ada dalam bank banyak yang menganggur,hal ini akan menimbulkan efek yang buruk dan menimbulkan biaya bagi bank. 


\section{SIMPULAN}

Berdasarkan hasil analisis pada bab sebelumnya dapat ditarik kesimpulan sebagai berikut :

Gambaran tingkat likuiditas Bank Nagari Cabang Painan selama periode 20142016 dapat disimpulkan bahwa :

1. Untuk rasio CR PT. Bank Nagari Cabang Painan tahun 2014-2016 dapat dikatakan sehat, karena berada diatas standar BI yaitu :
a) $>=4,05 \%$
: sehat
b) $>=3,30 \%-<4,05 \%$ : cukup sehat
c) $>2,55 \%-<3,30 \%$ : kurang sehat
d) $2,55 \% \quad$ : tidak sehat

2. Untuk rasio QR PT. Bank Nagari cabang Painan tahun 2014-2016 dapat dikatakan likuid jika QR berada diatas $100 \%$ atau 1:1, dan jika berada dibawah $80 \%$ atau 0,8:1 maka hal ini akan berdampak buruk bagi bank, karena akan dapat menimbulkan masalah bagi keuangan bank.

3. Untuk rasio LDR PT. Bank Nagari cabang Painan yangdiperoleh pada tahun 2014-2016 dapat dikatakan sehat, jika berada dibawah standar yang telah ditetapkan oleh BI yaitu :
a) $<=94,75 \% \quad$ : sehat
b) $>94,75 \%-98,50 \% \quad$ : cukup sehat
c) $>98,50 \%-<=102,25 \%$ : kurang sehat
d) $>102,25 \% \quad$ : tidak sehat

\section{DAFTAR PUSTAKA}

Alanshari, F., \& Marlius, D. (2018). Prosedur Pemberian Kredit KPR Pada PT. Bank Tabungan Negara (Persero) TBK Cabang Pembantu Bukittinggi. https://doi.org/10.31227/osf.io/rsfhc

Amelia, L., \& Marlius, D. (2018). Pengendalian Kredit Dalam Upaya Menciptakan Bank Yang Sehat Pada PT. Bank Pembangunan Daerah Sumatera Barat Cabang Utama Padang. https://doi.org/10.31227/osf.io/kpc64

Bank Indonesia, 2002, “ Studi dan Bantuan Likuiditas Bank Indonesia”

Bank Indonesia 1998 UU. No 10 tahun 1998 tentang “ Perubahan terhadap UU No 7 tahun 1992 ", Jakarta

Baiya, \& Fernos, J. (2019). Analisis Faktor-Faktor Penyebab Kredit Macet Pada Bank Nagari Cabang Siteba. https://doi.org/10.31227/osf.io/4xuks

Darmawanto, \& Fernos, J. (2019). Prosedur Pemberian Kredit Pada Bank Nagari Cabang Sijunjung. https://doi.org/10.31227/osf.io/psqfy 
Firmansyah, A., \& Fernos, J. (2019). Analisis Kredit Bermasalah Dilihat Dari Standar Non Performing Loan (NPL) Pada PT. Bank Perkreditan Rakyat (BPR) Prima Mulia Anugrah Cabang Padang. https://doi.org/10.31227/osf.io/gcj94

Jumingan, 2006 “ Analisis Laporan Keuangan ” Penerbit PT. Bumi Aksara, Jakarta

Kasmir, (2004) “ Manajemen Perbankan”, PT. Raja Grafindo Persada, Jakarta

Kasmir 2003, “ Bank dan Lembaga Keuangan Lainnya ” PT. Raja Grafindo Persada, Jakarta

Kasmir 2008, “Analisis Laporan Keuangan” Penerbit PT. Raja Grafindo

Munawir 1993 “Analisis Laporan Keuangan” Edisi keempat, Yogyakarta : liberti

PT. Bank Nagari Cabang Painan, 2014. “Laporan Tahunan atau Annual Report”. Digitized by USU digital library, 2002

Sawir Agnes, 2009 “Analisa Kinerja Keuangan dan Perencanaan Keuangan Perusahaan ". Jakarta PT. Gramedia Pustaka Umum

Shanjaya, A. R., \& Marlius, D. (2017). Peranan Laporan Keuangan Dalam Kebijaksanaan Pemberian Kredit Kepada Calon Nasabah Pada PT. BPR Batang Kapas. https://doi.org/10.31227/osf.io/uxmg6

Suyatno, Thomas, DRS, 1990. “Dasar-Dasar Perbankan”, Edisi Pertama, PT. Gramedia pustaka utama 